\title{
"Summer Syndrome" in Litopenaeus stylirostris in New Caledonia: Pathology and epidemiology of the etiological agent, Vibrio nigripulchritudo
}

\author{
Cyrille Goarant*, Dominique Ansquer, José Herlin, David Domalain, \\ Frédéric Imbert and Sophie De Decker
}

IFREMER, Département Aquaculture en Nouvelle-Calédonie, BP 2059, 98846 Nouméa cedex, New Caledonia

*: Corresponding author : Tel.: +687 2851 71; fax; +687 2878 57. Cyrille.Goarant@ifremer.fr

\begin{abstract}
The Summer Syndrome is a new shrimp disease that has been affecting a shrimp growout farm in New Caledonia since end of 1997. It was recognized to be caused by a systemic vibriosis due to Vibrio nigripulchritudo. This new disease turned out almost immediately enzootic in the shrimp farm involved and has affected all its crops ever since. Since the year 2000, V. nigripulchritudo strains have been found in several shrimp farms, although Summer Syndrome is still limited to one particular area, affecting, since 2003, two adjoining farms. As part of a multidisciplinary research program, a highfrequency survey was carried out during the summer 2002-2003 in two shrimp farms: one affected farm and another one in which pathogenic strains could be isolated but without any disease event. It permitted a good description of $\mathrm{V}$. nigripulchritudo dynamics in shrimp and the ecosystem in both farms. The study of virulence characteristics of some isolates showed that pathogenic and nonpathogenic strains occur in the shrimp farms environment and that both may be found at the same time in one farm. Our results strongly suggest a persistence of pathogenic strains in wet zones of the pond sediment at low concentrations between crops in the affected farm, and their development during the rearing cycle as a cause of shrimp infection.
\end{abstract}

Keywords: Shrimp; Diseases and their control; Vibrio; Epidemiology 


\section{Introduction}

Vibriosis is a major disease problem in almost all farmed marine animals, including penaeid shrimp (Lightner and Lewis, 1975; Takahashi et al., 1985; Lightner, 1988; Brock and Lea Master, 1992; Mohney and Lightner, 1994). However, it has only received poor research attention so very poor knowledge has been gained on this pathology. This is due, in part, to the authority given to treat with antibiotics in many producing countries. Nevertheless, the massive use of antibiotics has led to the selection of antibiotic-resistant bacterial strains (Brown, 1989; Holmström et al., 2003) and the inefficacy of such an approach. Furthermore, some producing countries, including New Caledonia, have totally banned the use of antibiotics in growout ponds and most importing countries have decreased tolerance on antimicrobial residues. Therefore, research programs on shrimp vibriosis are now being developed. New Caledonia is a small island country in the South Pacific and its shrimp industry benefits from an almost virus-free status, IHHNV being the only significant virus present, and its domestic stock of Litopenaeus stylirostris being resistant to it (Weppe et al., 1992). Still, from 1993 on, the shrimp growers had to face a seasonal vibriosis which was named Syndrome 93 (Goarant et al., 1996 and 1999; Mermoud et al., 1998). First observed in December 1997, a new vibriosis, which was named "Summer Syndrome", is causing increasing worries about the profitability of the industry. Therefore, the shrimp farmers' association is placing the research on vibriosis as the number one $R \& D$ priority. As a response, the Aquaculture Department of Ifremer (the French Institute for Marine Sciences) has developed a specific research program, named DeSanS (possibly translated as Stylirostris Health Challenge). This research program is based on a multidisciplinary approach associating rearing technology, pond ecosystem studies, shrimp ecophysiology and immunology, nutrition, pathology and genetics. It aims at gaining an overall explanation scheme of the seasonal vibriosis (Harache and Herbland, 2004) as a contribution to strengthen the sustainability of New Caledonian aquaculture.

\section{A brief history of the "Summer Syndrome”}

Vibrio nigripulchritudo was first isolated in New Caledonia in 1995 from diseased shrimp affected by the winter vibriosis Syndrome 93 (Costa et al., 1998). It was at this time restricted to two adjoining farms and was considered as a geographically restricted phenomenon (Goarant et al., 1999). Zoosanitary recommendations were given in order to minimize the risk of spreading of these pathogenic strains. However, V. nigripulchritudo was again isolated in late December 1997 in moribund shrimp from two ponds in one farm located 50 kilometres southern from the original isolation locations. It was also causing a septicemic vibriosis, but in high water temperature conditions that did not fit the Syndrome 93 epidemiology, which typically occurs when water temperature is below $25^{\circ} \mathrm{C}$ (Mermoud et al., 1998 ; Goarant et al., 2000). The histological findings indicated an acute systemic vibriosis (D.V. Lightner, com. pers.; J. Brock, com. pers. ; O. Ferré, com. pers.). Experimental infections using moribund shrimp carcasses ultrafiltrates failed to induce any mortality in healthy shrimp. This new disease was therefore considered as an acute systemic vibriosis caused by Vibrio nigripulchritudo. In the affected farm, the disease turned out almost immediately enzootic, with a very stereotyped epidemiology, taking place after 50 to 60 days rearing in every summer crop and causing high mortalities. Healthy carriers were frequently observed in the affected farm, both before, during and after the outbreaks (Goarant et al., 2004). $V$. nigripulchritudo was also isolated from both healthy and moribund shrimp in many other farms, in which it was not responsible for any significant mortality, or only caused low mortality with typical opportunistic features: affecting only a few molting animals or its expression could be related to inadequate pond conditions and stopped as soon as the conditions returned to normal. In the Summer Syndrome affected farm, strains of V. nigripulchritudo could also be isolated from pond water, sediment pore water, renewal water or associated with many Crustaceans both in the ponds and in the pumping water, and in zooplankton samples from the ponds (Goarant et al., 2004). The isolated strains demonstrated different virulence patterns in experimental infection with healthy 
shrimp. As part of the DeSanS program, a wide field survey was carried out during the 2002-2003 summer season based on a multidisciplinary approach to the Summer Syndrome (Harache and Herbland, 2004).

\section{Material and methods}

\section{Survey and growout ponds}

A survey was carried out in two 3-hectare earthen ponds: one pond in a farm that is affected by the Summer Syndrome (farm "DF" for Diseased Farm) and another pond in a farm in which the Summer Syndrome is not observed, though pathogenic V. nigripulchritudo strains have already been isolated (farm "HC” for Healthy Control) (Goarant et al., 2004). Both ponds were stocked on the same day with postlarvae (PL) originating from the same hatchery batch, with 28 PL.m ${ }^{-2}$ in farm DF and 35 PL.m ${ }^{-2}$ in farm HC. Both ponds were equipped with aerators. Shrimp were fed the same commercial feed pellet and managed by the technical staff of each own farm according to their usual techniques. After being drained from the previous crop, pond bottoms were ploughed and maintained as dry as possible, by pumping water in puddles. The ponds were filled ca. 2 weeks before seeding the postlarvae, according to each own farm's usual technique. The rearing period began in October 2002 and lasted until March 2003.

\section{Shrimp and mortality study}

Shrimp sampled with a castnet were considered healthy if displaying no lethargy or abnormal behaviour. Moribund shrimp were manually caught on the pond edges. Pond daily mortality was evaluated by counting dead and moribund shrimp on pond edges twice a day at 6.00 $\mathrm{AM}$ and 3.00 PM. Actually, an accurate estimation of daily mortality in a 3-ha shrimp pond is almost impossible, due to the wide area, high turbidity and cannibalism. Therefore, only a minor part of dead animals can be observed. Overall survival rates were calculated as the ratio of live shrimp harvested at the end of the growout period to the number of postlarvae initially seeded in the ponds.

\section{Sampling and analysis}

On the day of stocking, 100 postlarvae were randomly taken, rinsed with sterile seawater, crushed in an equal volume of sterile seawater and used for bacteriological analysis. Thirty healthy individual juvenile animals were then sampled on days 25 and 26 in farms DF and HC respectively. From day 32 on, 30 healthy individual juveniles were sampled on even dates in farm DF and on uneven dates in farm HC. Moribund shrimp were also sampled over the mortality period in order to confirm the aetiology of the outbreak. The haemolymph of juvenile shrimp (healthy or moribund) was withdrawn from the ventral sinus after rinsing with sterile seawater and used for bacteriological analysis. Pond water, sediment and renewal water were sampled at 6.00 AM, 3 and 2 days before stocking on farms DF and HC respectively, then on even dates in farm DF and on uneven dates in farm HC for renewal and pond water, and every 7 days for the sediment pore water. Pond water was hundred-fold diluted in sterile seawater. Sediment pore water was extracted by low-speed centrifugation (200 g for 5 minutes) and ten-fold diluted. Renewal water was ten-fold diluted. In any case, $100 \mu \mathrm{L}$ of all these diluted samples were used for bacteriological analysis in triplicate. All samples (crushed postlarvae, diluted water samples, heamolymph) were plated on Marine Agar with 2\% (w/v) glycerol added, on which V. nigripulchritudo colonies produce a dark grey to black pigment (Baumann and Schubert, 1984). Petri dishes were incubated for 72 hours at $30^{\circ} \mathrm{C}$. 
Colonies displaying a dark grey to black coloration were considered as presumptive $V$. nigripulchritudo. Some were isolated and the identification was confirmed by classical phenotypical tests: Gram, morphology, motility, oxydase and an API 20E strip (Bio Mérieux, Marcy l'Etoile, France). Lastly, if these tests were in agreement with the identification as $V$. nigripulchritudo, a PCR confirmation was obtained with the specific primers VnF (5'GTGTGAATTTAATAGATGCACATT-3' and VR (5'-CGCATCTGAGTGTCAGTATCT-3') with an annealing of 30 seconds at $58^{\circ} \mathrm{C}$ (Saulnier, unpublished data). The specificity of this PCR was validated over 18 Vibrio species, including the major shrimp pathogens (V. penaeicida, $V$. harveyi, $V$. alginolyticus, V. parahaemolyticus, $V$. vulnificus). The isolates were then preserved in $16 \%$ glycerol at $-80^{\circ} \mathrm{C}$.

\section{Strain virulence classification}

The V. nigripulchritudo strains were cultured in Marine Broth for 18 hours at $30^{\circ} \mathrm{C}$ under constant shaking, allowing to reach the late exponential growth phase. The bacterial culture concentrations were evaluated by reading their optical density at $600 \mathrm{~nm}$, as compared to a reference curve previously determined (data not shown). Fifty to 500 colony forming units were injected intramuscularly in healthy juvenile Litopenaeus stylirostris kept in aquaria (2 replicates aquaria with 8 to 10 shrimp in each for each strain) filled with filtered seawater, aerated and held at $27^{\circ} \mathrm{C}$. Additionally, higher concentrations of a non-virulent isolate were also injected to evaluate an effect of infective dose on this classification scheme. Control shrimp were injected an equal volume of sterile culture medium. Survival was followed over a 3-day period, because preliminary trials demonstrated that no significant mortality occurred after this duration. The experiment was validated only if all control shrimp survived. Most of the strains tested were isolated from farms studied during the survey, but additionally, strains from different origins were tested, in order to gain a better understanding of the epidemiology of V. nigripulchritudo in New Caledonian shrimp aquaculture.

\section{Results and discussion}

\section{Validity of the comparison:}

Though simple, the specificity of the method used for the counting of $V$. nigripulchritudo in the pond ecosystem and the haemolymph of both healthy and diseased shrimp was validated by phenotypic and PCR confirmation of 39 out of 43 strains (91\%) isolated during the survey. From this sampling, it can be assumed that $V$. nigripulchritudo counts during the survey have a reasonable specificity. Some mortality was observed, in farm DF only, after 50 days rearing (figure 1). In contrast, no mortality related to $V$. nigripulchritudo was observed in farm HC. The mortality in farm DF was confirmed to be typical "Summer Syndrome" by evidencing a septicemia caused by $V$. nigripulchritudo in 87 moribund shrimp out of 92 sampled at different time-points of the mortality peak between days 50 and 82. This confirms that the pond studied was affected by the same disease than previously observed and named Summer Syndrome. The overall survival rates were $27 \%$ and $62 \%$ in farms DF and HC respectively, which are also typical of the average survivals obtained in both farms during the last few years. 
Figure 1: Vibrio nigripulchritudo observed prevalence in shrimp from both farms and Summer Syndrome mortality in farm DF. Mortality is expressed as "daily number of moribund shrimp observed on pond edges" as explained in the text.

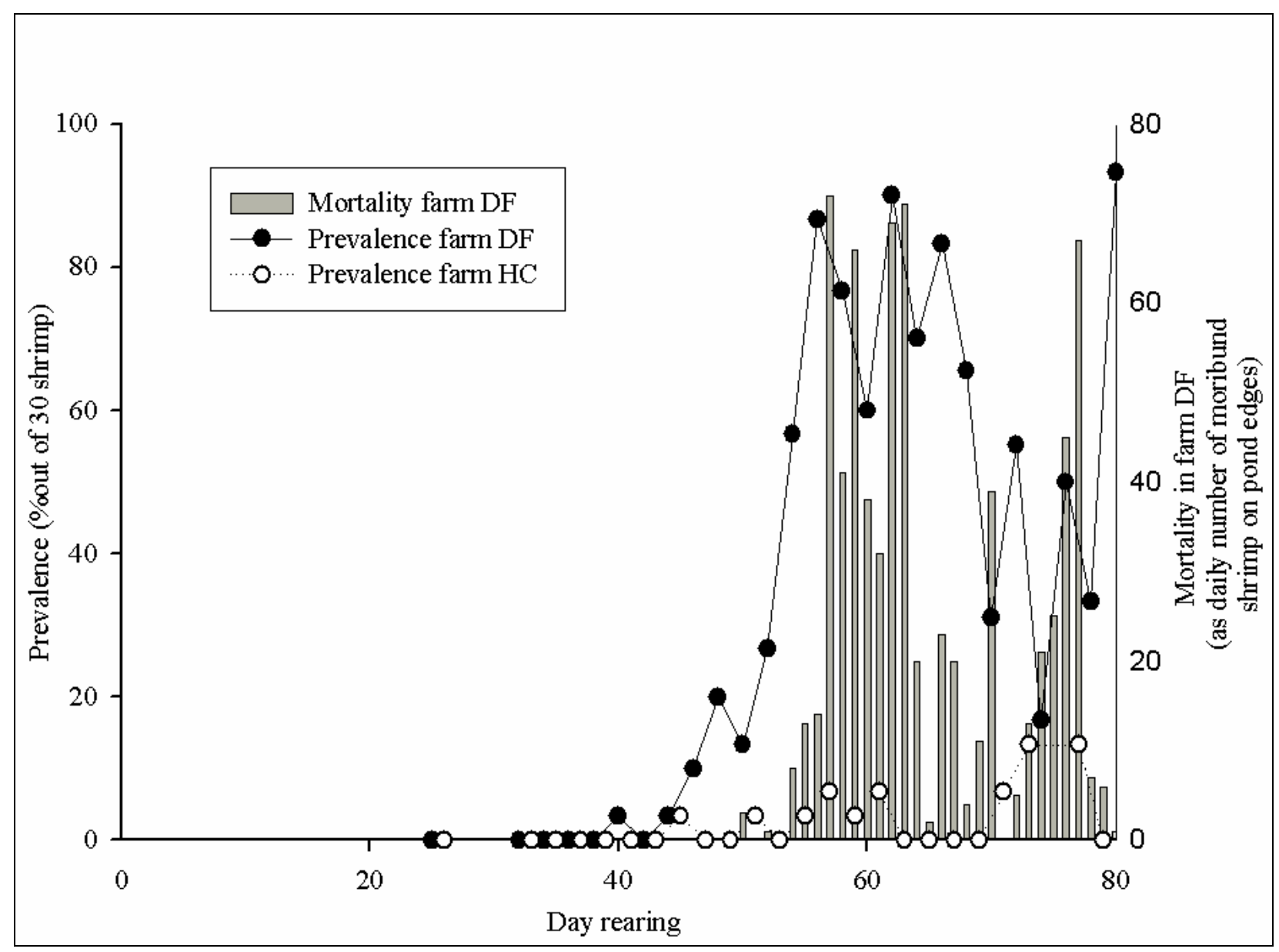

\section{Strain virulence classification}

Sixty nine $V$. nigripulchritudo strains, both clinical and environmental isolates, were tested by experimental infection. Cumulative mortality 72 hours after infection ranged from 0 to 100\%. The strains were considered as pathogenic if mortality was higher than $20 \%$ and non-pathogenic if mortality was under 20\%. A non-virulent isolate (SFn118) proved to be non-pathogenic even when injecting $7.5 \times 10^{4}$ CFU.shrimp ${ }^{-1}$. These results are summarized in table 1 . Current work is in progress to identify virulence genes in pathogenic $V$. nigripulchritudo isolates in order to permit a better distinction between pathogenic and non-pathogenic $V$. nigripulchritudo strains and to conduct a more accurate epidemiological description using virulence-based diagnostic tools (Gay et al., 2004). 
Table 1: Strain virulence classification of 69 Vibrio nigripulchritudo field isolates, indicating the isolation source, dose used for infection and survival after $\mathbf{7 2}$ hours. Experiments were conducted as described in Material and methods section.

Underlined strains were isolated during the survey (the rearing day is indicated for these strains).

Bold strains were isolated from farms affected by the Summer Syndrome.

Italics strains were isolated from Syndrome 93 (cool season) mortality episodes.

\begin{tabular}{|c|c|c|}
\hline strain & Farm & Source \\
\hline$\underline{\text { SFn127 }}$ & DF & healthy shrimp \\
\hline$\underline{\text { SFn128 }}$ & DF & moribund shrimp \\
\hline SFn142 & DF & renewal water \\
\hline$\underline{\text { SFn135 }}$ & DF & pond water \\
\hline$\underline{\text { SFn137 }}$ & DF & pond water \\
\hline SFn144 & DF & Sediment \\
\hline$\underline{\text { POn } 8}$ & $\mathrm{HC}$ & healthy shrimp \\
\hline POn 9 & $\mathrm{HC}$ & healthy shrimp \\
\hline$\underline{\text { POn } 12}$ & $\mathrm{HC}$ & healthy shrimp \\
\hline$\underline{\text { POn } 13}$ & $\mathrm{HC}$ & healthy shrimp \\
\hline$\underline{\text { POn } 14}$ & $\mathrm{HC}$ & healthy shrimp \\
\hline$\underline{\text { POn } 15}$ & $\mathrm{HC}$ & healthy shrimp \\
\hline$\underline{\text { POn } 16}$ & $\mathrm{HC}$ & healthy shrimp \\
\hline$\underline{\text { POn } 17}$ & $\mathrm{HC}$ & Sediment \\
\hline$\underline{\text { POn } 18}$ & $\mathrm{HC}$ & healthy shrimp \\
\hline$\underline{\text { POn } 19}$ & $\mathrm{HC}$ & healthy shrimp \\
\hline SFn1 & DF & moribund shrimp \\
\hline SFn2 & DF & moribund shrimp \\
\hline SFn27 & DF & sédiment \\
\hline SFn32 & DF & healthy shrimp \\
\hline SFn48 & DF & moribund shrimp \\
\hline SFn49 & DF & pond water \\
\hline SFn106 & DF & moribund shrimp \\
\hline SFn111 & DF & crab shell \\
\hline SFn115 & DF & renewal water \\
\hline SFn117 & DF & renewal water \\
\hline SFn118 & DF & renewal water \\
\hline
\end{tabular}
$\begin{array}{cc}\text { Day rearing (survey) } & \text { CFU.shrimp } \\ \text { or isolation date } & 1\end{array}$

$\begin{array}{ll}\text { d40 } & 383 \\ \text { d54 } & 319 \\ \text { d54 } & 925 \\ \text { d55 } & 774 \\ \text { d55 } & 396\end{array}$

$\begin{array}{lll}\mathrm{d} 60 & 514 & 100\end{array}$

$\begin{array}{lll}\mathrm{d} 45 & 116 & 83\end{array}$

$\begin{array}{lll}\mathrm{d} 51 & 94 & 100\end{array}$

$\begin{array}{lll}\mathrm{d} 71 & 53 & 100\end{array}$

$\begin{array}{lll}\mathrm{d} 73 & 68 & 100\end{array}$

$\begin{array}{lll}\mathrm{d} 73 & 40 & 83\end{array}$

$\begin{array}{lll}\mathrm{d} 73 & 47 & 100\end{array}$

$\begin{array}{lll}\mathrm{d} 71 & 556 & 100\end{array}$

$\begin{array}{lll}\mathrm{d} 73 & 700 & 100\end{array}$

$\begin{array}{lll}\mathrm{d} 77 & 294 & 100\end{array}$

$\begin{array}{lll}\mathrm{d} 77 & 700 & 0\end{array}$

March $2000 \quad 17,5 \quad 0$

March $2000 \quad 630 \quad 0$

December $2000 \quad 36 \quad 0$

December $2000 \quad 500 \quad 60$

November $2001 \quad 124 \quad 6$

November $2001 \quad 94 \quad 0$

February $2002 \quad 44,5 \quad 0$

March $2002 \quad 197 \quad 88$

March $2002 \quad 255 \quad 100$

April $2002 \quad 254 \quad 100$

April $2002 \quad 75 \quad 100$

$750 \quad 92$

$7500 \quad 100$

$75000 \quad 100$

$114 \quad 100$

$253 \quad 0$

$60-0$

$397 \quad 100$

$287 \quad 94$

$55 \quad 88$

$64 \quad 100$

$215 \quad 100$

$147 \quad 100$

$42 \quad 100$

$120 \quad 0$

$16 \quad 0$

$15 \quad 0$

$98 \quad 0$

10

$34-0$

145

121

$\begin{array}{ll}\text { March } 2003 & 145 \\ \text { March } 2003 & 121\end{array}$

0

0

0

0

0

6

AMn3 not affected moribund shrimp

,

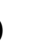

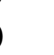

(1)

(6)

0

(1)

4

8

100




$\begin{array}{cccccc}\text { AMn5 } & \text { not affected } & \text { moribund shrimp } & \text { March 2003 } & 220 & 0 \\ \text { AQn1 } & \text { not affected } & \text { healthy shrimp } & \text { March 2003 } & 108 & 50 \\ \text { AQn2 } & \text { not affected } & \text { healthy shrimp } & \text { March 2003 } & 220 & 19 \\ \text { BDn1 } & \text { not affected } & \text { healthy shrimp } & \text { February 2003 } & 124 & 19 \\ \text { BDn2 } & \text { not affected } & \text { healthy shrimp } & \text { February 2003 } & 206 & 31 \\ \text { BLFn1 } & \text { not affected } & \text { moribund shrimp } & \text { March 2001 } & 530 & 27 \\ \text { BLFn2 } & \text { not affected } & \text { moribund shrimp } & \text { December 2001 } & 266 & 25 \\ \text { BLFn4 } & \text { not affected } & \text { moribund shrimp } & \text { December 2001 } & 383 & 31 \\ \text { ENn3 } & \text { not affected } & \text { healthy shrimp } & \text { June 2000 } & 600 & 100 \\ \text { ESn1 } & \text { not affected } & \text { healthy shrimp } & \text { June 2000 } & 320 & 100 \\ \text { ESn2 } & \text { not affected } & \text { healthy shrimp } & \text { June 2000 } & 200 & 100 \\ \text { ESn3 } & \text { not affected } & \text { healthy shrimp } & \text { June 2000 } & 450 & 92 \\ \text { Fn2 } & \text { not affected } & \text { healthy shrimp } & \text { February 2003 } & 112 & 94 \\ \text { FTn1 } & \text { not affected } & \text { moribund shrimp } & \text { January 2001 } & 233 & 88 \\ \text { FTn2 } & \text { not affected } & \text { healthy shrimp } & \text { March 2003 } & 86 & 38 \\ \text { MT 3 } & \text { not affected } & \text { healthy shrimp } & \text { June 2000 } & 420 & 100 \\ \text { SBn2 } & \text { not affected } & \text { healthy shrimp } & \text { March 2003 } & 148 & 38 \\ \text { SVn3 } & \text { not affected } & \text { healthy shrimp } & \text { February 2003 } & 195 & 100 \\ \text { Wn1 } & \text { not affected } & \text { moribund shrimp } & \text { January 2001 } & 46 & 56 \\ \text { Wn13 } & \text { not affected } & \text { moribund shrimp } & \text { January 2001 } & 106 & 50 \\ \text { Wn14 } & \text { not affected } & \text { moribund shrimp } & \text { November 2002 } & 89 & 50 \\ \text { Wn3 } & \text { not affected } & \text { moribund shrimp } & \text { November 2002 } & 60 & 50 \\ \text { SO65 } & \text { not affected } & \text { moribund shrimp } & \text { May 1995 } & 20 & 0 \\ \text { AM115 } & \text { not affected } & \text { moribund shrimp } & \text { May 1995 } & 146 & 12\end{array}$

\section{Animals}

$V$. nigripulchritudo could not be detected in the postlarvae seeded in the ponds. Furthermore, it has not been detected from other postlarvae batches during preliminary studies (unpublished data). Therefore, it can be considered that the postlarvae are V. nigripulchritudo-free at the time of stocking and that the animals get infected while in the growout ponds.

In farm HC, $V$. nigripulchritudo was first detected on day 45 in 1 shrimp out of 30 . It was then occasionally found, but in no more than 4 shrimp out of 30 (figure 1). Nine presumptive $V$. nigripulchritudo strains were isolated from healthy shrimp between days 45 and 77 and all confirmed to be $V$. nigripulchritudo. All but one tested as non-virulent when injected to healthy L. stylirostris. The only pathogenic strain was isolated from a presumed healthy shrimp on day 77, a few days before the end of the survey. Though isolated late in the growout period, this result demonstrates that highly pathogenic strains were also present in farm HC.

In farm DF, V. nigripulchritudo was first detected in shrimp (1 out of 30) on day 40 and the isolated strain proved to be virulent (see table 1). From day 46 on, the prevalence increased and then fluctuated between 5 and 28 shrimp out of 30 until the end of the survey (figure 1). The first moribund shrimp was observed on day 50, which is very typical of the Summer Syndrome. Interestingly, the increase in the mortality curve from day 50 to day 60 is almost parallel to the increase in prevalence from day 40 to day 50, suggesting that the disease has a latency phase of ca. 10 days. Pathogenic strains could be isolated from apparently healthy animals. Furthermore, after the first mortality peak, the prevalence fluctuates (figure 1). The overall survival in farm DF (27\%) also demonstrates that the prevalence can be higher (up to 28 out of 30) than the mortality. Taken together, these results indicate that $V$. nigripulchritudo is possibly cleared from the haemolymph and that shrimp that carry V. nigripulchritudo may remain healthy or even recover, as experimentally demonstrated with other Vibrio species (Alday-Sanz et al., 2002; Van-De-Braak et al., 2002). Different experimental infection modes are currently being studied as to investigate the course of infection (Saulnier et al., 2000) and possible recovery. 


\section{Pond ecosystem}

In farm HC, $V$. nigripulchritudo was neither detected in the water column nor in the renewal water. It was detected once in the sediment pore water, at low concentrations $\left(<20 \mathrm{CFU} . \mathrm{mL}^{-1}\right)$ and late in the growout period (day 73). This strain was isolated, confirmed to be V. nigripulchritudo but tested non-virulent when injected to healthy L. stylirostris (table 1). In contrast, in farm DF, $V$. nigripulchritudo was detected in the sediment pore water also at low concentrations (ca. 33 CFU.mL ${ }^{-1}$ ), but from day 11 on and until the onset of the mortality outbreak. Its concentration in the pore water increased during the disease outbreak (figure 2). It was also found in the water column on day 44, after its first detection in shrimp but short before the first observation of the mortality outbreak. It was then detected more frequently and at higher concentrations during the outbreak. It was detected only once in the renewal water, as a single colony on day 54, after the onset of the mortality. Thus in farm DF, both virulent and non-virulent strains were demonstrated in all compartments of the pond ecosystem (table 1). Regarding DF farm's surrounding environment, $V$. nigripulchritudo was only detected once in the renewal water, at a very low concentration and only after the onset of the mortality. This isolate was pathogenic, but former V. nigripulchritudo isolation from the pumping water only led to the isolation of three non-pathogenic strains (Goarant et al., 2004). This detection, though rare and late, indicates that the pathogen could enter the system via the renewal water, but only at low concentrations. However, it was found earlier (from day 11 on), at higher concentrations and very frequently in the sediment pore water. The detection sequence in the affected farm (sediment at day 11 , shrimp at day 40 , pond water at day 44, renewal water at day 54) probably reflects the differences in abundance between the compartments and suggests that low concentrations of $V$. nigripulchritudo could survive in wet zones of the pond sediment during the dry-out period, then re-colonize larger zones of the sediment when the pond is filled up. Actually, there always exist wet zones of sediment in a 3-ha pond, even after long dry-out times, in which Vibrio strains would be able to persist. The overwintering at low levels in sediments was also described in Vibrio parahaemolyticus (Colwell, 1983). Shrimp ponds sediments are known as a rich medium prone to favour the growth of the Vibrio flora (Burford et al., 1998; Kautsky et al., 2000; La Rosa et al., 2001). Actually, it seems that V. nigripulchritudo strains can easily find a place in the ecology of farm DF, whereas it remains at a very low level in farm HC. This suggests that some factors present in farm DF's ecosystem, and especially sediments, may favour V. nigripulchritudo as compared to farm HC's ecosystem. If so, a complete disinfection procedure (Bell and Lightner, 1992) of farm DF could help prevent the re-occurrence of the Summer Syndrome. Work is currently in progress to investigate if some sediment parameters in farm DF may favour the growth of $V$. nigripulchritudo. 
Figure 2: Water temperature and presumptive Vibrio nigripulchritudo counts in pond water and sediment pore water in farm DF. The grey bar on X-axis represents the mortality period.

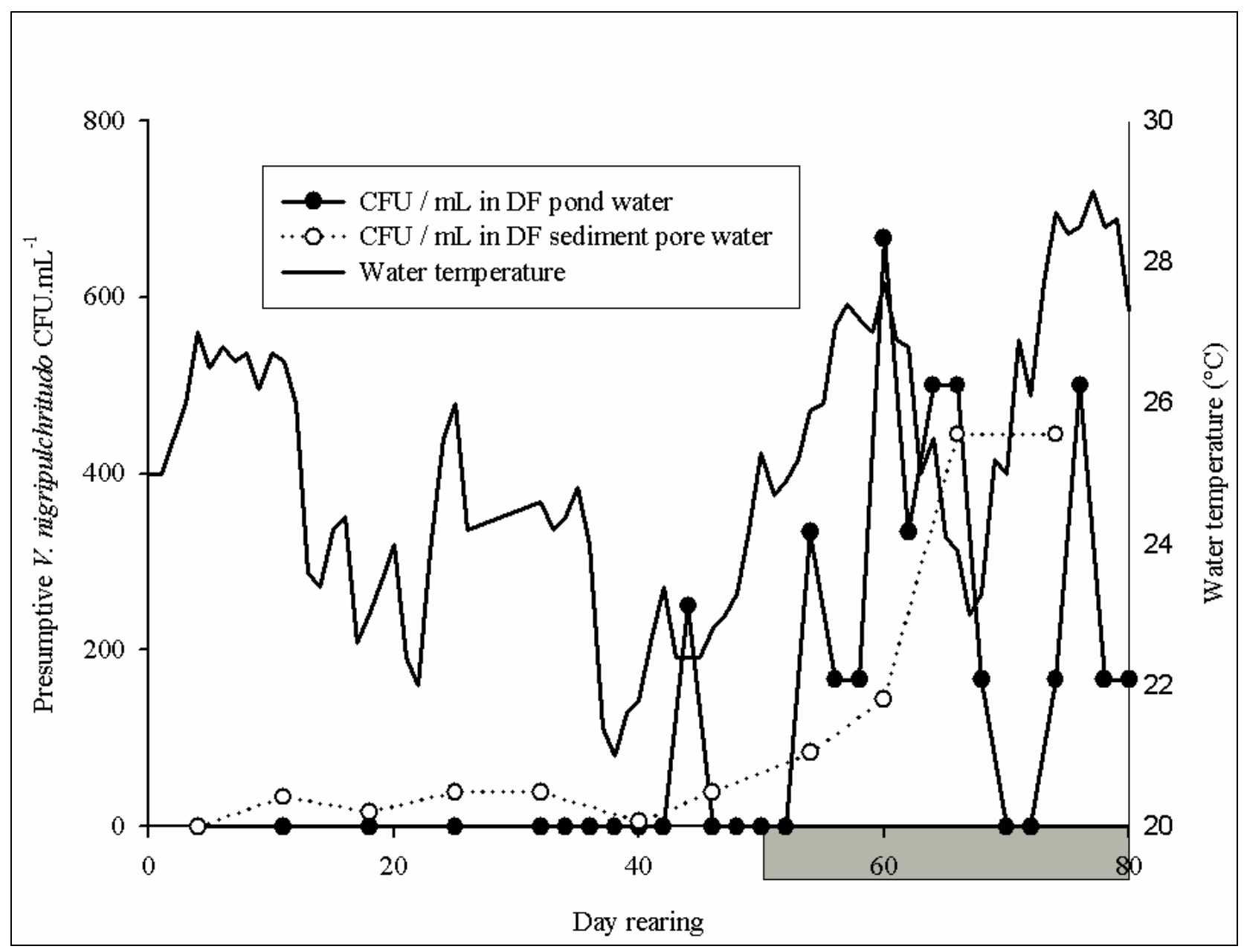

Lastly, the survey demonstrated a growth of planktonic crustaceans short before the onset of the epizootic in farm DF, evoking possible ecological relationships between $V$. nigripulchritudo and the zooplankton, as described for other Vibrio species, like V. parahaemolyticus (Kaneko and Colwell, 1975 ; Venkateswaran et al., 1989) or V. cholerae (Huq et al., 1983). Attempts to transform one pathogenic $V$. nigripulchritudo strain with a plasmid encoding the constitutive expression of Green Fluorescent Protein (GFP) are currently undertaken, that would permit the study of these relationships, as done with $V$. cholerae (Chiavelli et al., 2001).

\section{Comparison between farms}

Very clear differences were observed between the two farms: In the healthy control farm (HC), V. nigripulchritudo was remaining at a low prevalence in shrimp until the end of the survey. Furthermore, all strains isolated before day 77 were non-pathogenic. It was detected only once and lately in the sediment. This infrequent detection means that $V$. nigripulchritudo was either absent or remained at low concentrations within HC farm's ecosystem during the survey. In contrast, in the affected farm (DF), both virulent and non-virulent $V$. nigripulchritudo were isolated from all compartments. From day 46 on, the rapid increase in prevalence suggests that either the phenomenon has turned to the epizootic mode, i.e. cross-contamination between infected (and/or moribund) and non-infected shrimp may occur or shrimp are exposed to high infective doses. This 
ends up with the onset of the mortality outbreak, on day 50. Therefore, the Summer Syndrome can be considered as a disease that implicates environmental strains, as described in other shrimp vibriosis. An increase in population of the pathogenic Vibrio species was observed in our study, as also described with other studies on shrimp vibriosis (Lavilla-Pitogo et al., 1998; Sung et al., 1999). However, the contemporary detection of virulent and non-virulent strains in the ecosystem also suggests that a more complex "microbial ecology problem" could be one of the key factors in the Summer Syndrome.

\section{Acknowledgments}

Thanks are due to the staff of farms DF and HC for welcoming us during the survey and providing the zootechnical data, to all Ifremer members who helped during the survey, namely $\mathrm{P}$. Brun, D. Coatanea, L. Dellapatrona, E. Goyard, K. Justou, C. Lambert, A. Legrand, P. Lemaire, H. Lemonnier, A.L. Marteau, C. Mugnier, J. Patrois, J.M. Peignon, E. Pita, B. Soulard.

This work was partly supported by grants from the South and North Provinces of New Caledonia, Ifremer and the French Ministry of Research. 


\section{References}

Alday-Sanz, V., Roque, A., Turnbull, J.F., 2002. Clearing mechanisms of Vibrio vulnificus biotype I in the black tiger shrimp Penaeus monodon. Dis. Aquat. Org. 48, 91-99.

Bell, T. A., Lightner, D. V., 1992. Shrimp facility clean-up and re-stocking procedures. Monograph \#192015 Department of Veterinary Science, The University of Arizona, Tucson, Arizona 85721. 23 pp.

Baumann, P., Schubert. R.H.W., 1984. Section 5. Facultatively anaerobic Gram-negative rods, Family II. Vibrionaceae. In Bergey's Manual of Systematic Bacteriology, Vol. 1. J.G. Holt and N.R. Krieg (Eds.), p. 516-550. Williams \& Wilkins Co, Baltimore, MD.

Brock, J. A., LeaMaster, B., 1992. A look at the principal bacterial, fungal and parasitic diseases of farmed shrimp. In J. Wyban (Ed.), Proceedings of the Special Session on Shrimp Farming. World Aquaculture Society, Baton Rouge, La. pp. 212-226

Brown, J.H., 1989. Antibiotics: their use and abuse in aquaculture. World Aquaculture 20, 34-49.

Burford, M.A., Peterson, E.L., Baiano, J.C.F., Preston, N.P., 1998. Bacteria in shrimp pond sediments: their role in mineralizing nutrients and some suggested sampling strategies. Aquac. Res. 29, 843-849.

Chiavelli, D.A., Marsh, J.W., Taylor, R.K., 2001. The mannose-sensitive hemagglutinin of Vibrio cholerae promotes adherence to zooplankton. Appl. Environ. Microbiol. 67, 3220-3225.

Colwell, R.R., 1983. Vibrios in the environment. John Wiley \& Sons, New York. 625 pages.

Costa, R., Mermoud, I., Koblavi, S., Morlet, B., Haffner, P., Berthe, F., Le Groumellec, M., Grimont, P., 1998. Isolation and characterization of bacteria associated with a Penaeus stylirostris disease (Syndrome 93) in New Caledonia. Aquaculture 164, 297-309.

Gay, M., Saulnier, D., Faury, N., Le Roux F., 2004. Vers une étude épidémiologique des vibrioses. In : Styli 2003. Trente ans de crevetticulture en Nouvelle-Calédonie. Nouméa-Koné, 2-6 juin 2003. Éd. Ifremer, Actes Colloq., 38. p 196-202.

Goarant, C., Herlin, J., Ansquer, D., Imbert, F., Domalain, D., Marteau A.L., 2004. Épidémiologie de Vibrio nigripulchritudo dans le cadre du Syndrome d'été : résultats préliminaires du programme DESANS. In : Styli 2003. Trente ans de crevetticulture en Nouvelle-Calédonie. Nouméa-Koné, 2-6 juin 2003. Éd. Ifremer, Actes Colloq., 38. p 210-215

Goarant, C., Herlin, J., Brizard, R., Marteau, A.L., Martin, C., Martin, B., 2000. Toxic factors of Vibrio strains pathogenic to shrimp. Dis. Aquat. Org. 40, 101-107.

Goarant, C., Mérien, F., Berthe, F., Mermoud, I., Pérolat, P., 1999. Arbitrarily primed PCR to type Vibrio spp. pathogenic for shrimp. Appl. Environ. Microbiol. 65, 1145-1151.

Goarant, C., Mermoud, I., Costa, R., Haffner, P., Boglio, E., 1996. Study of episodes of mortality observed in reared Penaeus stylirostris since 1993 in New Caledonia: I. Biotechnical impact and gross signs in diseased prawns. World Aquaculture Society editor. Book of abstracts World Aquaculture Society annual conference. pp. 139-140. 96.

Harache, Y., Herbland, A., 2004. Le programme DESANS (Défi Santé Stylirostris) : une démarche comparable au Défi MOREST appliquée à la filière crevette Calédonienne. In : Styli 2003. Trente 
ans de crevetticulture en Nouvelle-Calédonie. Nouméa-Koné, 2-6 juin 2003. Éd. Ifremer, Actes Colloq., 38. p 31-38.

Holmström, K., Gräslund, S., Wahström, A., Poungshompoo, S., Bengtsson, B.E., Kautsky, N., 2003. Antibiotic use in shrimp farming and implications for environmental impacts and human health. International Journal of Food Science and Technology 38, 255-266.

Huq, A., Small, E.B., West, P.A., Huq, M.I., Rahman, R., Colwell, R.R., 1983. Ecological relationships between Vibrio cholerae and planktonic crustacean copepods. Appl. Environ. Microbiol. 45, 275-283.

Kaneko, T., Colwell, R.R., 1975. Adsorption of Vibrio parahaemolyticus onto chitin and Copepods. Appl. Microbiol. 29, 269-274.

Kautsky, N., Ronnback, P., Tedengren, M., Troell, M., 2000. Ecosystem perspectives on management of disease in shrimp pond farming. Aquaculture 191, 145-161.

La-Rosa, T., Mirto, S., Marino, A., Alonzo, V., Maugeri, T.L., Mazzola, A., 2001. Heterotrophic bacteria community and pollution indicators of mussel - farm impact in the Gulf of Gaeta (Tyrrhenian Sea). Mar. Environ. Res. 52, 301-321.

Lavilla-Pitogo, C.R., Leaño, E.M., Paner, M.G., 1998. Mortalities of pond-cultured juvenile shrimp, Penaeus monodon, associated with dominance of luminescent vibrios in the rearing environment. Aquaculture 164, 337-349.

Lightner, D.V., 1988. Vibrio disease of penaeid shrimp. In C. J. Sindermann and D. V. Lightner (ed.), Disease diagnosis and control in North American marine aquaculture. Elsevier, Amsterdam, The Netherlands. pp. 42-47.

Lightner, D.V., Lewis, D.H., 1975. A septicemic bacterial disease syndrome of penaeid shrimp. Mar. Fish. Rev. 37, 25-28.

Mermoud, I., Costa, R., Ferré, O., Goarant, C., Haffner, P., 1998. Syndrome 93 in New Caledonian outdoor rearing ponds of Penaeus stylirostris : history and description of the three major outbreaks. Aquaculture 164, 323-335.

Mohney, L.L., Lightner, D.V., 1994. An epizootic of vibriosis in Ecuadorian pond-reared Penaeus vannamei Boone (Crustacea: Decapoda). J. World Aquacult. Soc. 25, 116-125.

Saulnier, D., Haffner, P., Goarant, C., Levy, P., Ansquer, D., 2000. Experimental infection models for shrimp vibriosis studies : a review. Aquaculture 191, 133-144.

Sung, H.H., Li, H.C., Tsai, F.M., Ting, Y.Y., Chao, W.L. 1999. Changes in the composition of Vibrio communities in pond water during tiger shrimp (Penaeus monodon) cultivation and in the hepatopancreas of healthy and diseased shrimp. J. Exp. Mar. Biol. Ecol. 236, 261-271.

Takahashi, Y., Y. Shimomaya, Momomaya, K., 1985. Pathogenicity and characteristics of Vibrio sp. isolated from cultured kuruma prawns Penaeus japonicus Bate. Bull. Jpn. Soc. Sci. Fish. 51, 721-730.

Van-De-Braak, C.B., Botterblom, M.H.A., Taverne, N., Van-Muiswinkel, B., Rombout, J.H.W.M., Van-Der-Knaap, W.P.W., 2002. The roles of haemocytes and the lymphoid organ in the clearance of injected Vibrio bacteria in Penaeus monodon shrimp. Fish Shellfish Immun. 13, 293-309. 
Venkateswaran, K., Kim, S.W., Nakano, H., Onbé, T., Hashimoto, H. 1989. The association of Vibrio parahaemolyticus serotypes with zooplancton and its relationship with bacterial indicators of pollution. Syst. Appl. Microbiol. 11, 194-201.

Weppe, M., Bonami, J.R., Lightner, D.V. AQUACOP., 1992. Demostración de la altas cualidades de la cepa de $P$. stylirostris (AQUACOP SPR 43) resistente al virus IHHN. in Memorias I Congreso Ecuatoriano de acuicultura, Ed. : Escuela Superior Politécnica del Litoral, 1993 pp. 229-232. 